Article

\title{
Timing of a Short-Term Reduction in Temperature and Irradiance Affects Growth and Flowering of Four Annual Bedding Plants
}

\author{
Jennifer K. Boldt * $*$ and James E. Altland \\ United States Department of Agriculture, Agricultural Research Service, Application Technology Research Unit, \\ Wooster, OH 44691, USA; James.Altland@ars.usda.gov \\ * Correspondence: Jennifer.Boldt@ars.usda.gov; Tel.: +1-419-530-2225
}

Received: 7 December 2018; Accepted: 23 January 2019; Published: 1 February 2019

check for updates

\begin{abstract}
Heating and supplemental lighting are often provided during spring greenhouse production of bedding plants, but energy inputs are a major production cost. Different energy-savings strategies can be utilized, but effects on plant growth and flowering must be considered. We evaluated the impact and timing of a two-week low-energy (reduced temperature and irradiance) interval on flowering and growth of impatiens (Impatiens walleriana Hook.f. 'Accent Orange'), pansy (Viola $\times$ wittrockiana Gams. 'Delta Premium Blue Blotch'), petunia (Petunia $\times$ hybrida Hort. Vilm.-Andr. 'Dreams Pink'), and snapdragon (Antirrhinum majus L. 'Montego Violet'). Flowering was delayed 7 to 10 days when the low-energy exposure occurred before flowering. Flower number was reduced 40-61\% in impatiens, 33-35\% in petunia (low-energy weeks 5-6 and weeks 7-8, respectively), and $35 \%$ in pansy (weeks 5-6). Petunia and impatiens dry mass gradually decreased as the low-energy exposure occurred later in production; petunias were $26 \%$ (weeks 5-6) and 33\% (weeks 7-8) smaller, and impatiens were $20 \%$ to $31 \%$ smaller than ambient plants. Estimated energy savings were $14 \%$ to $16 \%$ for the eight-week period, but only up to $7 \%$ from transplant to flowering. Growers can consider including a two-week reduction in temperature and irradiance to reduce energy, provided an additional week of production is scheduled.
\end{abstract}

Keywords: temperature; irradiance; ornamental plants; greenhouse production

\section{Introduction}

Greenhouse production of annual bedding plants for spring markets occurs in late winter and early spring. Heating and supplemental lighting are often provided to offset low outdoor temperatures and augment low solar irradiation intensity and duration. Consequently, energy inputs are a major production cost for greenhouse-grown plants. In the United States, energy is the third largest expense after labor and plant material, and it accounted for $9 \%$ of total production costs in the 2014 Census of Horticultural Specialties [1]. Approximately $65 \%$ to $85 \%$ of total greenhouse energy consumption is for heating [2].

Irradiance drives photosynthesis and primarily influences crop growth and dry weight gain. Temperature primarily influences crop development, including rates of leaf unfolding, flower initiation, and flower development. Together, light and temperature impact crop timing and quality. The ratio of radiant energy (light) to thermal energy (temperature), or RRT, is one way to describe this [3]. A higher RRT increases crop quality; for example, plants grown at lower temperatures and higher irradiance (high RRT) will be of higher quality than plants grown at higher temperatures and lower irradiance (low RRT). This ratio is an indicator of plant carbon balance, which becomes depleted under prolonged exposure to high temperature and low irradiance [4]. For example, starch levels in rose (Rosa $\times$ hybrida 
'Red Berlin') were similar when plants were exposed to high temperature and high irradiance or low temperature and low irradiance but were diminished under high temperature and low irradiance [4].

Crops need to meet both a target market date and minimum quality standards. Lighting and temperature set points can be adjusted during production to address economic and environmental concerns. Growers are continually looking for strategies to reduce energy consumption and costs without sacrificing plant growth, quality, and/or finished time. Therefore, it is important to evaluate different production strategies and determine when they may be feasible to implement. Surveys have found $55 \%$ to $58 \%$ of responding U.S. growers have implemented conservation or energy efficient practices [5,6]. Installing an energy or thermal screen is one strategy for reducing energy use [2], but only $12 \%$ of respondents in one of the surveys had them [5]. Other viable production strategies for reducing energy use include growing in unheated greenhouses or high tunnels [7], using root zone heating [8], or using a reduced temperature to finish (RTF) [9].

Many growers maintain static air temperature set points, independent of ambient weather conditions outside [10]. Allowing the greenhouse temperature to rise above the desired mean daily temperature (MDT) when heating demand is low and fall below the desired MDT when heating demand is high, but maintain the same MDT, is another strategy to reduce energy use [11]. These temperature integration strategies have been referred to as dynamic temperature control [2], integrating temperature control [12], multi-day temperature setting [13], or dynamic photosynthetic optimization [14]. While MDT remains the same, a wider range of acceptable temperature fluctuations is allowed. This can be accomplished by increasing the daytime ventilation set point and decreasing the nighttime heating set point, using a computer algorithm to maintain a rolling MDT and adjust temperatures based on predicted weather patterns [15], or using a computer algorithm to adjust greenhouse conditions based on photosynthetic optimization [14,16] or plant assimilate balance [13]. Temperatures need to remain within the linear range of plant development rate, between the base temperature $\left(\mathrm{T}_{\text {base }}\right.$; development rate $\left.=0\right)$ and the optimum temperature $\left(\mathrm{T}_{\mathrm{opt}}\right.$; development rate is maximal) for each species to minimize delays in development [17].

Dynamic temperature management can be integrated on a $24 \mathrm{~h}[11,18]$, multi-day [15], or weekly basis $[19,20]$. It has been successful for roses [12,21], potted plants [18,22], and vegetables [19] when the amplitude of the bandwidth was $\leq \pm 6^{\circ} \mathrm{C}$. One drawback, however, is that dynamic heating requires a greenhouse environmental control computer with sophisticated software, and not all growers have or can afford these systems [2]. For greenhouses without environmental control systems, an energy-reduction alternative is to optimize the growing environment on days with a lower heating requirement (i.e. warmer, sunnier, and or less windy) and reduce energy inputs (lower the temperature, turn off supplemental lighting, and close the energy curtain) on days that require more heating. This short-term reduction in temperature and irradiance was successful when implemented 1 to 2 days per week, with reduced energy costs and minimal impact on plant growth and crop timing [23,24]. However, weather patterns often are cyclical on a longer time scale, and growers may contend with days to weeks of continuous cloudy weather during winter and early spring. Condensing the low temperature and irradiance exposure into a continuous time period rather than interspersed throughout production may impact its successful implementation, even though it is for a similar total number of days. Therefore, our objective was to evaluate the timing of a two-week reduction in temperature and irradiance on plant growth and flowering of four popular annual bedding plant crops and estimate potential cost savings using the Virtual Grower software program. We selected cold-tolerant [pansy $($ Viola $\times$ wittrockiana Gams.) and snapdragon (Antirrhinum majus L.)], cold-intermediate [petunia (Petunia $\times$ hybrida Hort. Vilm.-Andr.)], and cold-sensitive [impatiens (Impatiens walleriana Hook.f.)] species, as categorized by their $\mathrm{T}_{\text {base }}[25,26]$.

\section{Materials and Methods}

Seeds of impatiens 'Accent Orange', pansy 'Delta Premium Blue Blotch', petunia 'Dreams Pink', and snapdragon 'Montego Violet' were sown on 15 December 2014 (replication 1) and 6 January 
2015 (replication 2) into 288-cell plug trays filled with a peat-based soilless substrate (LC-1; Sun Gro Horticulture, Bellevue, WA). Trays were placed in a growth chamber (GR48; Environmental Growth Chambers, Chagrin Falls, OH) set to provide $25{ }^{\circ} \mathrm{C}$ constant air temperature, $300 \mu \mathrm{mol} \cdot \mathrm{m}^{-2} \cdot \mathrm{s}^{-1}$ photosynthetic photon flux density (PPFD) from high-pressure sodium (HPS) lamps, and an $8 \mathrm{~h}$ photoperiod. They were watered as needed, and provided $75 \mathrm{mg} \cdot \mathrm{L}^{-1} \mathrm{~N}$ constant liquid feed of 20N-4.4P-16.6K (Jack's 20-10-20; JR Peters, Inc., Allentown, PA, USA) at each irrigation once true leaves emerged.

Two greenhouse environments were set up in identical compartments located within a glass-glazed greenhouse (Toledo, $\mathrm{OH}, \mathrm{USA}$ ). The ambient compartment represented typical greenhouse conditions during winter and early spring. Temperature set points were $22{ }^{\circ} \mathrm{C}$ day/18 ${ }^{\circ} \mathrm{C}$ night. High-pressure sodium light fixtures (Sunlight Supply, Inc., Vancouver, WA, USA) provided approximately $75 \mu \mathrm{mol} \cdot \mathrm{m}^{-2} \cdot \mathrm{s}^{-1}$ of supplemental irradiance from 1000-W bulbs (Osram Sylvania Products, Inc., Manchester, NH, USA) when ambient PPFD at the benchtop was less than $300 \mu \mathrm{mol} \cdot \mathrm{m}^{-2} \cdot \mathrm{s}^{-1}$, and a constant $14 \mathrm{~h}$ photoperiod (0600-2000 HR) was maintained. The cool compartment represented a cool, low light environment. Temperature set points were $13^{\circ} \mathrm{C}$ day $/ 10^{\circ} \mathrm{C}$ night. A spun-woven energy curtain was continuously closed, which reduced ambient irradiance by approximately $50 \%$, relative to ambient conditions. Day-extension lighting with HPS lamps was provided when ambient irradiance was less than $10 \mu \mathrm{mol} \cdot \mathrm{m}^{-2} \cdot \mathrm{s}^{-1}$ PPFD to achieve a constant $14 \mathrm{~h}$ photoperiod. Dataloggers (HOBO®Pro v2; Onset Applications, Bourne, MA, USA) in each environment measured air temperature. Quantum sensors (Model QSO-S; Apogee Instruments, Logan, UT, USA) were connected to a data logger (CR10X; Campbell Scientific, Logan, UT, USA) and mean PPFD was recorded every $15 \mathrm{~min}$.

On 20 January and 9 February 2015, plants were transplanted into $11.5 \mathrm{~cm}$ diameter round pots filled with LC-1. They were irrigated as needed during the experiment. Plants were watered once weekly with reverse-osmosis water and fertilized with $20 \mathrm{~N}-4.4 \mathrm{P}-16.6 \mathrm{~K}$ at an $\mathrm{N}$ concentration of $150 \mathrm{mg} \cdot \mathrm{L}^{-1}$ at all other irrigation events. Electrical conductivity (EC) and $\mathrm{pH}$ of the substrate solution was monitored every two weeks on three additional plants of each species grown continuously in the ambient and cool, low light environments, using the Pour-Through technique, to ensure values remained within the recommended ranges for all species [27].

Plants were moved from ambient conditions to the cool, low light environment for a two-week interval during the eight-week duration of the experiment (i.e., weeks $1-2$, weeks $3-4$, weeks $5-6$, or weeks 7-8 in cool, low light, with the other 6 weeks in ambient conditions). Two additional treatments included a continuous ambient control and a continuous cool, low light control. There were five plants per species per treatment. Mean air temperatures and daily light integrals (DLIs) are provided in Table 1.

Table 1. Mean air temperature $\left({ }^{\circ} \mathrm{C}\right.$ ) and daily light integral (DLI, mol $\left.\cdot \mathrm{m}^{-2} \cdot \mathrm{d}^{-1}\right)$ for each treatment. Plants were grown in ambient conditions $\left[22 / 18{ }^{\circ} \mathrm{C}\right.$ air temperature, $14 \mathrm{~h}$ photoperiod, and ambient irradiance $+75 \mu \mathrm{mol} \cdot \mathrm{m}^{-2} \cdot \mathrm{s}^{-1}$ supplemental lighting from high-pressure sodium (HPS) lamps when photosynthetic photon flux density (PPFD) was less than $300 \mu \mathrm{mol} \cdot \mathrm{m}^{-2} \cdot \mathrm{s}^{-1}$ ] and transferred to cool, low light conditions $\left(13 / 10^{\circ} \mathrm{C}\right.$ air temperature, ambient irradiance, and a $14 \mathrm{~h}$ photoperiod achieved by providing $75 \mu \mathrm{mol} \cdot \mathrm{m}^{-2} \cdot \mathrm{s}^{-1}$ from HPS lamps when PPFD was less than $10 \mu \mathrm{mol} \cdot \mathrm{m}^{-2} \cdot \mathrm{s}^{-1}$ ) at 2-week intervals during an 8-week production cycle.

\begin{tabular}{|c|c|c|c|c|c|}
\hline \multirow{2}{*}{ Treatment } & \multirow{2}{*}{$\begin{array}{c}\text { Target Mean } \\
\text { Temperature }\left({ }^{\circ} \mathrm{C}\right)\end{array}$} & \multicolumn{2}{|c|}{ Mean Temperature $\left({ }^{\circ} \mathrm{C}\right)$} & \multicolumn{2}{|c|}{$\operatorname{DLI}\left(\mathrm{mol} \cdot \mathrm{m}^{-2} \cdot \mathrm{d}^{-1}\right)$} \\
\hline & & Replication 1 & Replication 2 & Replication 1 & Replication 2 \\
\hline Ambient & 20.3 & $20.3 \pm 1.7$ & $20.3 \pm 1.7$ & $10.7 \pm 3.0$ & $12.8 \pm 3.4$ \\
\hline Weeks $1-2$ cool & 18.2 & 18.3 & 18.7 & 10.2 & 11.6 \\
\hline Weeks 3-4 cool & 18.2 & 18.5 & 18.3 & 9.7 & 11.3 \\
\hline Weeks 5-6 cool & 18.2 & 18.5 & 18.6 & 9.4 & 10.9 \\
\hline Weeks 7-8 cool & 18.2 & 18.5 & 18.4 & 8.9 & 10.7 \\
\hline Cool & 11.8 & $12.9 \pm 1.1$ & $13.2 \pm 1.4$ & $6.1 \pm 1.5$ & $6.3 \pm 1.9$ \\
\hline
\end{tabular}


Flowering was checked daily, and date of first flower was recorded. Eight weeks after transplant, flower number was counted. Relative chlorophyll content (CCM-200; Apogee Instruments, Inc., Logan, UT) was measured on three recently mature leaves per plant, and the mean value was used for statistical analysis. Plant height was measured from the substrate surface to the apex. Plant width was measured at the widest point and perpendicular to the widest point, then the two measurements were averaged. Above-ground plant tissue was removed, washed with $0.1 \mathrm{~N} \mathrm{HCl}$, rinsed with ultra-purified $(18 \mathrm{M} \Omega)$ water, dried in a forced-air oven at $60{ }^{\circ} \mathrm{C}$ for 3 days, and weighed for dry mass.

A virtual greenhouse was constructed to estimate daily heating and supplemental lighting costs for each environment, using the USDA-ARS software program Virtual Grower 3.0.9 (USDA-ARS, Toledo, $\mathrm{OH}, \mathrm{USA}$ ). Greenhouse dimensions, materials, and components were as described previously [24]. Total energy costs for each treatment were calculated (1) as the sum of daily energy costs for the eight-week production duration, and (2) as the sum of daily energy costs from the start of the experiment to mean date of the first flower, based on the temperature and supplemental lighting schedules.

Data were analyzed as a randomized complete block design, with six treatments, five single-plant replications per treatment, and repeated twice in time. A separate analysis was conducted for each species. Data were analyzed in SAS (SAS 9.3; SAS Institute, Inc., Cary, NC, USA) using the GLM procedure (PROC GLM) and mean separation was conducted with Tukey's HSD at $\alpha=0.05$ for significant treatment effects $(P \leq 0.05)$.

\section{Results and Discussion}

Length of production is a critical benchmark for greenhouse growers, as increased production time reduces the number of crop cycles per season and increases the fixed costs allocated to each crop. Flowering is important for quick sell-through at retail, and therefore, time to flower is an important scheduling metric. Compared to control plants grown at ambient conditions, flowering was delayed when plants were provided with a two-week low-energy interval early in production. This occurred in all crops grown in the cool, low light environment in weeks 1-2 or weeks $3-4$, and additionally in petunia in weeks 5-6 (Table 2). The delay in flowering was 7 to 10 days. Ambient control plants began flowering during week 5 of production (29 to 35 days after transplant); mean days to flower was 30, 32, 34 , and 34 days in pansy, impatiens, snapdragon, and petunia, respectively. As such, the absence of delayed flowering on plants exposed to the low-energy exposure in weeks 5-6 or weeks 7-8 occurred because plants were budded or flowering before the start of the cool, low light exposure.

Continuous exposure to low-energy conditions delayed flowering by more than 3 weeks, compared to ambient controls (Table 2). Incomplete flowering occurred in impatiens and snapdragon by the end of the experiment, 8 weeks after transplant, and none of the petunias had flowered. Minimum temperature $\left(\mathrm{T}_{\mathrm{min}}\right)$ values for flower development of 2.0 to $4.0^{\circ} \mathrm{C}$ have been reported for snapdragon, 2.8 to $5.5^{\circ} \mathrm{C}$ for petunia, $4.1{ }^{\circ} \mathrm{C}$ for viola (Viola cornuta L. 'Sorbet Plum Velvet'), and $7.2^{\circ} \mathrm{C}$ for impatiens 'Blitz 3000 Deep Orange' [25,26]. Although we used different cultivars in our study, the $10{ }^{\circ} \mathrm{C}$ nighttime set point in the low-energy treatment was greater than the $T_{\min }$ for all species. Therefore, flowering would have eventually occurred, but the delay and variability of flowering does not make continuous low-energy conditions a viable production strategy for most species. 
Table 2. Plant growth and flowering of impatiens (Impatiens walleriana 'Accent Orange'), pansy (Viola $\times$ wittrockiana 'Delta Premium Blue Blotch'), petunia (Petunia $\times$ hybrida 'Dreams Pink'), and snapdragon (Antirrhinum majus 'Montego Violet') grown in ambient conditions (ambient), grown in ambient conditions and transferred to a low-energy environment at two-week intervals during an eight-week production cycle, or grown continuously in the low-energy environment (continuous). Ambient conditions were $22 / 18^{\circ} \mathrm{C}$ air temperature, $14 \mathrm{~h}$ photoperiod, and ambient irradiance $+75 \mu \mathrm{mol} \cdot \mathrm{m}^{-2} \cdot \mathrm{s}^{-1}$ supplemental lighting from high-pressure sodium (HPS) lamps when photosynthetic photon flux density (PPFD) was less than $300 \mu \mathrm{mol} \cdot \mathrm{m}^{-2} \cdot \mathrm{s}^{-1}$. Low-energy conditions were $13 / 10^{\circ} \mathrm{C}$ air temperature, ambient irradiance, and a $14 \mathrm{~h}$ photoperiod achieved by providing $75 \mu \mathrm{mol} \cdot \mathrm{m}^{-2} \cdot \mathrm{s}^{-1}$ from HPS lamps when PPFD was less than $10 \mu \mathrm{mol} \cdot \mathrm{m}^{-2} \cdot \mathrm{s}^{-1}$.

\begin{tabular}{|c|c|c|c|c|c|c|c|c|}
\hline Crop & Treatment & CCI (4 Weeks after Transplant) & CCI (8 Weeks after Transplant) & Height $(\mathrm{cm})$ & Width (cm) & Dry Mass (g) & Flower Number & Days to Flower \\
\hline \multirow{8}{*}{ Impatiens } & Ambient & $55.5 \pm 3.1$ & $56.7 \pm 3.4$ & $19.9 \pm 0.7$ & $42.1 \pm 1.4$ & $14.9 \pm 0.6$ & $58.2 \pm 5.9$ & $32 \pm 2$ \\
\hline & Weeks 1-2 & $37.9 \pm 1.5$ & $57.6 \pm 2.9$ & $18.4 \pm 0.9$ & $38.4 \pm 0.9$ & $11.9 \pm 0.5$ & $34.8 \pm 2.6$ & $43 \pm 2$ \\
\hline & Weeks 3-4 & $30.2 \pm 1.5$ & $51.4 \pm 2.7$ & $16.8 \pm 0.8$ & $35.8 \pm 1.4$ & $10.9 \pm 0.6$ & $22.9 \pm 2.2$ & $42 \pm 2$ \\
\hline & Weeks 5-6 & $57.4 \pm 3.1$ & $59.5 \pm 3.6$ & $18.0 \pm 1.0$ & $36.2 \pm 1.5$ & $10.9 \pm 0.3$ & $28.3 \pm 2.6$ & $37 \pm 3$ \\
\hline & Weeks 7-8 & $57.1 \pm 3.3$ & $53.5 \pm 4.0$ & $16.0 \pm 0.9$ & $34.3 \pm 1.4$ & $10.3 \pm 0.6$ & $26.8 \pm 4.6$ & $38 \pm 2$ \\
\hline & Continuous & $13.1 \pm 1.0$ & $34.7 \pm 1.4$ & $9.9 \pm 1.0$ & $15.1 \pm 0.8$ & $1.1 \pm 0.1$ & $0.3 \pm 0.2$ & $54 \pm 2$ \\
\hline & ANOVA $^{z}$ & $<0.0001$ & $<0.0001$ & $<0.0001$ & $<0.0001$ & $<0.0001$ & $<0.0001$ & $<0.0001$ \\
\hline & $\mathrm{HSD}_{0.05}{ }^{\mathrm{y}}$ & 10.3 & 13.3 & 2.8 & 4.0 & 2.2 & 14.8 & 8 \\
\hline \multirow{7}{*}{ Pansy } & Ambient & $75.4 \pm 1.3$ & $60.8 \pm 4.1$ & $12.3 \pm 0.6$ & $16.6 \pm 1.1$ & $3.3 \pm 0.4$ & $11.1 \pm 0.9$ & $30 \pm 1$ \\
\hline & Weeks 1-2 & $61.5 \pm 2.8$ & $63.5 \pm 2.3$ & $13.0 \pm 0.6$ & $17.7 \pm 1.2$ & $3.6 \pm 0.6$ & $8.9 \pm 0.7$ & $38 \pm 2$ \\
\hline & Weeks 5-6 & $71.2 \pm 3.2$ & $74.7 \pm 3.3$ & $11.5 \pm 0.6$ & $17.2 \pm 0.9$ & $3.9 \pm 0.5$ & $7.2 \pm 1.0$ & $37 \pm 3$ \\
\hline & Weeks 7-8 & $65.7 \pm 4.2$ & $60.6 \pm 3.0$ & $14.1 \pm 0.4$ & $18.8 \pm 0.9$ & $3.4 \pm 0.3$ & $8.0 \pm 0.8$ & $33 \pm 2$ \\
\hline & Continuous & $43.1 \pm 2.3$ & $67.3 \pm 3.1$ & $11.2 \pm 0.8$ & $15.3 \pm 0.4$ & $1.8 \pm 0.1$ & $0.9 \pm 0.2$ & $54 \pm 1$ \\
\hline & ANOVA & $<0.0001$ & 0.0505 & 0.0051 & 0.0211 & $<0.0001$ & $<0.0001$ & $<0.0001$ \\
\hline & $\mathrm{HSD}_{0.05}$ & 12.1 & - & 2.3 & 2.9 & 1.1 & 3.6 & 7 \\
\hline \multirow{7}{*}{ Petunia } & Ambient & $27.8 \pm 1.2$ & $38.9 \pm 1.7$ & $21.8 \pm 0.7$ & $42.7 \pm 1.0$ & $15.3 \pm 0.9$ & $41.7 \pm 2.4$ & $35 \pm 1$ \\
\hline & Weeks 1-2 & $20.1 \pm 1.0$ & $34.3 \pm 1.5$ & $20.7 \pm 0.6$ & $42.9 \pm 1.4$ & $13.5 \pm 0.4$ & $37.6 \pm 2.8$ & $42 \pm 1$ \\
\hline & Weeks 3-4 & $16.0 \pm 0.4$ & $35.8 \pm 1.2$ & $20.6 \pm 1.0$ & $40.6 \pm 0.7$ & $14.1 \pm 0.5$ & $34.1 \pm 3.0$ & $42 \pm 1$ \\
\hline & Weeks 5-6 & $25.7 \pm 1.2$ & $34.1 \pm 1.4$ & $22.1 \pm 1.0$ & $37.5 \pm 1.2$ & $11.4 \pm 0.8$ & $28.0 \pm 2.8$ & $42 \pm 1$ \\
\hline & Weeks 7-8 & $26.4 \pm 1.3$ & $30.7 \pm 2.4$ & $20.7 \pm 0.9$ & $37.4 \pm 1.3$ & $10.2 \pm 0.7$ & $27.2 \pm 1.5$ & $33 \pm 1$ \\
\hline & Continuous & $18.8 \pm 1.2$ & $23.1 \pm 1.1$ & $13.7 \pm 0.8$ & $23.1 \pm 0.7$ & $3.3 \pm 0.2$ & $0.0 \pm 0.0$ & - \\
\hline & $\mathrm{HSD}_{0.05}$ & 4.6 & 6.6 & 3.5 & 3.8 & 2.1 & 8.1 & 5 \\
\hline \multirow{8}{*}{ Snapdragon } & Ambient & $65.2 \pm 4.9$ & $60.2 \pm 3.1$ & $18.6 \pm 0.7$ & $22.5 \pm 0.6$ & $7.2 \pm 0.7$ & $61.2 \pm 8.3$ & $34 \pm 1$ \\
\hline & Weeks 1-2 & $66.0 \pm 2.0$ & $62.4 \pm 3.7$ & $19.5 \pm 0.8$ & $23.8 \pm 0.6$ & $7.1 \pm 0.6$ & $48.3 \pm 5.6$ & $41 \pm 2$ \\
\hline & Weeks 3-4 & $62.8 \pm 3.3$ & $62.2 \pm 3.4$ & $20.4 \pm 0.4$ & $23.1 \pm 0.7$ & $6.2 \pm 0.5$ & $57.5 \pm 3.5$ & $40 \pm 2$ \\
\hline & Weeks 5-6 & $62.7 \pm 5.2$ & $73.3 \pm 4.0$ & $21.9 \pm 1.0$ & $23.4 \pm 0.7$ & $6.4 \pm 0.6$ & $53.8 \pm 5.0$ & $38 \pm 2$ \\
\hline & Weeks 7-8 & $63.9 \pm 4.6$ & $63.5 \pm 3.0$ & $18.8 \pm 0.8$ & $22.4 \pm 0.6$ & $6.0 \pm 0.4$ & $53.3 \pm 4.2$ & $34 \pm 1$ \\
\hline & Continuous & $51.2 \pm 2.2$ & $51.9 \pm 2.5$ & $22.8 \pm 1.0$ & $24.1 \pm 0.5$ & $4.3 \pm 0.3$ & $0.1 \pm 0.1$ & $60 \pm 2$ \\
\hline & ANOVA & 0.0199 & 0.0003 & 0.0004 & 0.1822 & $<0.0001$ & $<0.0001$ & $<0.0001$ \\
\hline & $\mathrm{HSD}_{0.05}$ & 13.2 & 11.9 & 3.0 & - & 1.5 & 16.7 & 4 \\
\hline
\end{tabular}

${ }^{\mathrm{z}}$ Analysis of variance; ${ }^{\mathrm{y}}$ Tukey's honest significant difference $(\alpha=0.05)$. 
Delayed flowering with the low-energy exposure was primarily due to the lower overall temperature. Increased days to flower in response to decreased temperature have been reported for impatiens 'Accent Red', pansy 'Delta Yellow Blotch', petunia 'Easy Wave Coral Pink' and 'Wave Purple', and snapdragon 'Chimes White', but not for impatiens 'Super Elfin White' [28-32]. For example, a 23 days delay in flowering occurred in snapdragon 'Chimes White' when temperature decreased from 20 to $10{ }^{\circ} \mathrm{C}$ [30]. In previous studies, time to flower for petunia 'Easy Wave Coral Pink' and petunia 'Wave Purple' increased as MDT decreased from 26 to $14^{\circ} \mathrm{C}$, and time to flower for pansy 'Delta Yellow Blotch' increased linearly as MDT decreased from 25.7 to $16.3^{\circ} \mathrm{C}$ [28,29]. Finally, a 3 to 4 days delay in flowering of impatiens 'Super Elfin Lipstick', petunia 'Avalanche Pink', and pansy 'Colossus Yellow Blotch' was documented for each $1{ }^{\circ} \mathrm{C}$ reduction in temperature [33], which is consistent with the 7 to 10 day delay in flowering we observed in our study when providing a two-week low-energy exposure (overall mean temperature was 1.6 to $2.0^{\circ} \mathrm{C}$ lower than the ambient treatment; Table 1).

Decreased irradiance in the low-energy conditions may have also contributed to delayed flowering, which has been reported for impatiens 'Super Elfin White', snapdragon 'Rocket Rose', pansy 'Delta Yellow Blotch', and petunia 'Snow Cloud' [29,32,34]. Snapdragon 'Rocket Rose' flowering was delayed 21 days, and impatiens 'Super Elfin White' flowering was delayed 4 days, but only at high temperatures, when DLI decreased from 21.8 to $10.5 \mathrm{~mol} \cdot \mathrm{m}^{-2} \cdot \mathrm{d}^{-1}$ [32]. The influence of DLI on flowering is often attributed to meristem heating by the increased irradiance intensity, and, therefore, is a temperature effect as well [35].

The two-week low-energy exposure also decreased flower number and plant growth relative to those grown at ambient conditions. Flower number in impatiens, pansy, and petunia, but not snapdragon, decreased compared to ambient controls (Table 2). Impatiens was most sensitive, and a two-week low-energy exposure at any point during production reduced flower number $40 \%$ to $61 \%$. Pansy flower number was lower only in the weeks 5-6 exposure $(35 \%)$, and petunia flower number was lower only in the weeks 5-6 and weeks 7-8 exposures (33\% and 35\%, respectively). Comparing across the four two-week low-energy treatments, timing did not influence impatiens, pansy, or snapdragon flower number, although petunias in low-energy weeks 1-2 had more flowers than the other low-energy intervals. This suggests implementation of a two-week low-energy exposure would not affect flower number regardless of when it was applied during production. Snapdragon inflorescence number was similar across the ambient control and four low-energy treatments (12 to 13 inflorescences), and higher than in the continuous low-energy treatment ( $<1$ inflorescence; data not shown).

Reduced flower number was likely due to both a delay in flowering and reduced net photosynthesis in the low-energy environment. Light is a primary driver of photosynthesis, and temperature influences the rates of enzymatic activity and carbon loss via photorespiration. A decrease in petunia flower development rate as mean DLI decreased from 14 to $4 \mathrm{~mol} \cdot \mathrm{m}^{-2} \cdot \mathrm{d}^{-1}$ has been reported [28]. Likewise, petunia 'Snow Cloud' grown at temperatures ranging from 10 to $30{ }^{\circ} \mathrm{C}$ flowered 3 to 23 days later at a given temperature when provided a DLI of $6 \mathrm{~mol} \cdot \mathrm{m}^{-2} \cdot \mathrm{d}^{-1}$ rather than $13 \mathrm{~mol} \cdot \mathrm{m}^{-2} \cdot \mathrm{d}^{-1}$ [34]. A reduction in flower number was observed in petunia 'Supertunia Vista Bubblegum' and 'Supertunia Mini Strawberry Pink Veined' grown 2 days or more per week in low-energy conditions and in pansy 'Matrix Blue Blotch' grown 4 days per week or continuously in low-energy conditions, compared to plants grown continuously in ambient conditions [24].

Relative chlorophyll content index (CCI) four weeks after transplant was generally lower in plants exposed to low-energy conditions, i.e., the weeks $1-2$, weeks $3-4$, and continuous treatments (Table 2). After eight weeks, relative CCI was not affected by the timing of the low-energy exposure, when compared to ambient conditions. The continuous low-energy treatment had lower CCI values for impatiens and petunia but not pansy or snapdragon (Table 2). This may be related to their cold tolerance, as impatiens and petunia are more cold-sensitive than pansy and snapdragon $[25,26]$. The reduction in relative CCI is likely a response to the lower temperature. In cotton (Gossypium hirsutum 
L. var. Delta Pine 61), chlorophyll concentration decreased as temperature decreased [36]. Chlorophyll concentration in tomato (Solanum lycopersicon L. cv. M-19) and pepper (Capsicum annuum L. cv. M-71) decreased by almost half after a 12 days chilling $\left(5^{\circ} \mathrm{C}\right)$ treatment [37]. Although relative chlorophyll content rather than total chlorophyll concentration was measured in this study, it is an accepted proxy [38].

Plant height was unaffected by the timing of the low-energy exposure in impatiens and petunia. Except for the weeks 7-8 low-energy exposure, which was similar to the ambient control, snapdragon plant height increased with a two-week low-energy exposure (5\% to $18 \%$ increase; Table 2 ). We observed an increase in shoot height previously in dianthus 'Telstar Pink' as the number of days per week in low-energy conditions increased [24]. Additionally, shoot height of some Kalanchoe species increased as DLI decreased from 17.2 to 4.3 to $\mathrm{mol} \cdot \mathrm{m}^{-2} \cdot \mathrm{d}^{-1}$ [39]. It appears a period of lower DLI during the vegetative phase elicited a shade avoidance response in snapdragon. The timing of the weeks 7-8 low-energy treatment occurred after flowering had begun, and therefore, did not affect internode length nor cause elongation of the inflorescence peduncle.

Plant diameter generally was unaffected or smaller when the timing of the two-week low-energy exposure occurred later in production. Snapdragon plant diameter was similar across all treatments and pansy was smaller only when grown in continuous low-energy conditions (Table 2). Impatiens and petunia plant diameters were smaller than the ambient controls when the two-week low-energy interval occurred later in production, in weeks 3-4 or later or in weeks 5-6 or later, respectively.

Similar to plant height and width, pansy and snapdragon dry mass were smaller only in plants grown continuously in the low-energy conditions ( $46 \%$ and $40 \%$, respectively; Table 2). Petunia and impatiens dry mass gradually decreased as the two-week low-energy exposure occurred later in production. Petunias grown in weeks $5-6$ or weeks $7-8$ were $26 \%$ and $33 \%$ smaller, respectively, than ambient controls. Any two-week low-energy exposure in impatiens, regardless of the timing, reduced final dry mass $(20 \%$ to $31 \%)$. The sensitivity of each species to dry mass accumulation corresponds to their cold tolerance; pansy and snapdragon are considered cold-tolerant annuals, petunia is a cold-intermediate species, and impatiens is a cold-sensitive species. The smaller plant size and dry mass is likely the result of reduced photosynthesis at lower irradiance and temperature, which reduced carbohydrate availability for growth. Previously, a decrease in plant dry mass of eight annual bedding plants was observed as DLI decreased, including impatiens 'Cajun Red' and petunia 'Apple Blossom' [40]. Additionally, pansy 'Delta Yellow Blotch' plant mass decreased in response to decreased irradiance, and pansy 'Universal Violet' dry mass decreased as temperature decreased [29,41].

Estimated energy costs were calculated for two production durations. First, energy costs were calculated for the total eight-week production period and relativized to energy costs in the ambient environment. Energy costs in our greenhouse were $84 \%$ to $86 \%$ of ambient when the two-week low-energy exposure was provided (Table 3). Energy costs increased slightly as the timing of the low-energy period occurred later in production due to naturally increasing temperatures and irradiance from late winter to early spring. The continuous low-energy environment had the lowest energy costs, at $44 \%$ of ambient. The second energy calculation estimated energy costs from transplant to mean date of the first flower for each species. This accounted for the lower per day cost in the low-energy conditions but the extended time of production due to delayed flowering. More modest reductions in energy costs occurred, ranging from a $7 \%$ reduction to a $17 \%$ increase in energy costs compared to the ambient environment (Table 3). Energy costs for the continuous low-energy treatment were not calculated due to the lack of $100 \%$ flowering after eight weeks. The estimated energy savings of $4 \%$ to $6 \%$ when pansy, petunia, and snapdragon were grown in cool, low light conditions during weeks $1-2$ of production are slightly lower than the $8 \%$ to $18 \%$ energy savings reported for other dynamic temperate integration strategies [11,12,16], but much less than the $19 \%$ to $46 \%$ savings reported [14]. Additionally, snapdragons grown for two weeks in cool, low light conditions generally exhibited the lowest relative energy costs of the four species evaluated, compared to plants grown in ambient conditions, while impatiens generally had the highest relative energy costs. This corresponds 
to the plant growth and flowering data and is reflective of their classification as cold-tolerant and cold-sensitive species, respectively.

Table 3. Percent energy costs, relative to ambient conditions, calculated in Virtual Grower 3.0.9 using parameters specified [24]. Ambient conditions were $22 / 18{ }^{\circ} \mathrm{C}$ air temperature, $14 \mathrm{~h}$ photoperiod, and ambient irradiance $+75 \mu \mathrm{mol} \cdot \mathrm{m}^{-2} \cdot \mathrm{s}^{-1}$ supplemental lighting from high-pressure sodium (HPS) lamps when photosynthetic photon flux density (PPFD) was less than $300 \mu \mathrm{mol} \cdot \mathrm{m}^{-2} \cdot \mathrm{s}^{-1}$. Low-energy conditions were $13 / 10^{\circ} \mathrm{C}$ air temperature, ambient irradiance, and a $14 \mathrm{~h}$ photoperiod achieved by providing $75 \mu \mathrm{mol} \cdot \mathrm{m}^{-2} \cdot \mathrm{s}^{-1}$ from HPS lamps when PPFD was less than $10 \mu \mathrm{mol} \cdot \mathrm{m}^{-2} \cdot \mathrm{s}^{-1}$. Impatiens (Impatiens walleriana 'Accent Orange'), pansy (Viola $\times$ wittrockiana 'Delta Premium Blue Blotch'), petunia (Petunia $\times$ hybrida 'Dreams Pink'), and snapdragon (Antirrhinum majus 'Montego Violet') were grown in ambient conditions (ambient), grown in ambient conditions and transferred to a low-energy environment at two-week intervals during an eight-week production cycle, or grown continuously in the low-energy environment (continuous).

\begin{tabular}{|c|c|c|c|c|c|}
\hline \multirow{2}{*}{ Treatment } & \multirow{2}{*}{$\begin{array}{l}\text { Relative Cumulative } \\
\text { Energy Cost }{ }^{z}\end{array}$} & \multicolumn{4}{|c|}{ Relative Cumulative Energy Cost at Flowering y } \\
\hline & & Impatiens & Pansy & Petunia & Snapdragon \\
\hline Ambient & $100 \%$ & $100 \%$ & $100 \%$ & $100 \%$ & $100 \%$ \\
\hline Weeks 1-2 cool & $84 \%$ & $103 \%$ & $96 \%$ & $94 \%$ & $95 \%$ \\
\hline Weeks 3-4 cool & $86 \%$ & $101 \%$ & $98 \%$ & $98 \%$ & $93 \%$ \\
\hline Weeks 5-6 cool & $86 \%$ & $99 \%$ & $102 \%$ & $99 \%$ & $97 \%$ \\
\hline Weeks 7-8 cool & $88 \%$ & $117 \%$ & $106 \%$ & $94 \%$ & $100 \%$ \\
\hline Continuous & $44 \%$ & $-x$ & - & - & - \\
\hline
\end{tabular}

$\mathrm{z}$ Total energy costs after 8 weeks, reported as a relative percent compared to plants grown continuously in ambient conditions; ${ }^{y}$ Energy costs were calculated from transplant to flowering and reported as a relative percent compared to plants grown continuously in ambient conditions; ${ }^{x}$ Not all plants had flowered after 8 weeks, and therefore energy costs were not calculated.

One of our objectives was to evaluate the effectiveness of a two-week low-energy interval as a strategy to reduce energy costs for greenhouse production of spring bedding plants. In all species, flowering was the most sensitive and was delayed in all species if the low-energy exposure was applied before flowering. The timing of the two-week low energy exposure influenced the severity of the impact on plant growth. It minimally affected pansy and snapdragon, regardless of when the two-week interval was applied. Petunia was more impacted when the interval was applied in the second half of production, and impatiens dry mass was affected regardless of the week. Therefore, depending on species and target plant size, the timing of the low-energy exposure could be shifted earlier in production to have a minimal impact on plant size and dry mass, or later in production to have a more pronounced effect on final plant size. For example, shifting the exposure later in production may provide a non-chemical strategy for growth regulation of species and cultivars with a vigorous plant habit.

Additionally, we wanted to evaluate the possibility of applying the intermittent short-term reduction in temperature and irradiance as a continuous two-week exposure rather than for 1 to 2 days per week, as reported previously [24], to better align with weather patterns and energy demands. Overall mean temperature and DLI for a crop will be similar when the cumulative duration of low-energy conditions is the same, whether provided continuously for a period of time or intermittently throughout production. Therefore, it stands to reason flowering time would be similar if crops are able to integrate temperature throughout the period of flower initiation and development, as long as temperatures remain between $\mathrm{T}_{\min }$ and $\mathrm{T}_{\text {opt }}$. In our study, pansy, petunia, and snapdragon grown in low-energy conditions for 2 days per week flowered within 2 days of plants exposed to low-energy conditions for a two-week period in weeks 1-2, weeks 3-4, or weeks 4-6 (data not shown). A comparison was not made with impatiens due to insufficient seedling number for the intermittent low-energy treatments.

In conclusion, flowering and plant growth were negatively impacted by the addition of a two-week low-energy exposure, resulting in delayed flowering, fewer flowers, and reduced plant size, mass, 
and relative chlorophyll content. Cold-sensitive crops, like impatiens, will be most severely impacted. Results from this study indicate the inclusion of a two-week low-energy exposure would decrease energy costs over an eight-week period but have a nominal reduction or even increase in overall energy consumption from transplant to flowering due to delays in flowering. Therefore, it could be worthwhile for growers to consider a short-term intermittent reduction in temperature and DLI to reduce heating costs, but only for cold-tolerant species like snapdragon and if an extra week of production can be built into the production schedule.

Author Contributions: Conceptualization, J.K.B.; Investigation, J.K.B.; Methodology, J.K.B. and J.E.A.; Project administration, J.K.B.; Writing - original draft, J.K.B.; Writing - review and editing, J.K.B. and J.E.A.

Funding: This research received no external funding.

Conflicts of Interest: The authors declare no conflict of interest.

Disclaimer: Mention of trade names or commercial products in this publication is solely for the purpose of providing specific information and does not imply recommendation or endorsement by the U.S. Department of Agriculture. USDA is an equal opportunity provider and employer.

\section{References}

1. United States Department of Agriculture. 2012 Census of Agriculture: Census of Horticultural Specialties (2014). AC-12-SS-3. 2015. Available online: https://www.nass.usda.gov/Publications/AgCensus/2012/ Online_Resources/Census_of_Horticulture_Specialties/HORTIC.pdf (accessed on 19 November 2018).

2. Runkle, E.; Both, A.J. Greenhouse Energy Conservation Strategies; Extension Bulletin E-3160; Michigan State University: East Lansing, MI, USA, 2011.

3. Liu, B.; Heins, R.D. Is plant quality related to the ratio of radiant energy to thermal energy? Acta Hortic. 1997, 435, 171-182. [CrossRef]

4. Dieleman, J.A.; Meinen, E. Interacting effects of temperature integration and light intensity on growth and development of single-stemmed cut rose plants. Sci. Hortic. 2007, 113, 182-187. [CrossRef]

5. Dennis, J.H.; Lopez, R.G.; Behe, B.K.; Hall, C.R.; Yue, C.; Campbell, B.J. Sustainable production practices by greenhouse and nursery plant growers. HortScience 2010, 45, 1232-1237. [CrossRef]

6. Hall, T.J.; Dennis, J.H.; Lopez, R.G.; Marshall, M.I. Factors affecting growers' willingness to adopt sustainable floriculture practices. HortScience 2009, 44, 1346-1351. [CrossRef]

7. Currey, C.J.; Lopez, R.G.; Mattson, N.S. Finishing bedding plants: A comparison of an unheated high tunnel versus a heated greenhouse in two geographic locations. HortTechnology 2014, 24, 527-534. [CrossRef]

8. Olberg, M.W.; Lopez, R.G. Growth and development of poinsettia (Euphorbia pulcherrima) finished under reduced air temperature and bench-top root-zone heating. Sci. Hortic. 2016, 210, 197-204. [CrossRef]

9. Camberato, D.M.; Lopez, R.G.; Krug, B.A. Development of Euphorbia pulcherrima under reduced finish temperatures. HortScience 2012, 47, 745-750. [CrossRef]

10. Dieleman, J.A.; Meinen, E.; Marcelis, L.F.M.; de Zwart, H.F.; van Henten, E.J. Optimisation of $\mathrm{CO}_{2}$ and temperature in terms of crop growth and energy use. Acta Hortic. 2005, 691, 149-154. [CrossRef]

11. Rijsdijk, A.A.; Vogelezang, J.V.M. Temperature integration on a 24-hour base: A more efficient climate control strategy. Acta Hortic. 2000, 519, 163-169. [CrossRef]

12. Buwalda, F.; Rijsdijk, A.A.; Vogelezang, J.V.M.; Hattendorf, A.; Batta, L.G.G. An energy efficient heating strategy for cut rose production based on crop tolerance to temperature fluctuations. Acta Hortic. 1999, 507, 117-125. [CrossRef]

13. Elings, A.; de Zwart, H.F.; Janse, J.; Marcelis, L.F.M.; Buwalda, F. Multiple-day temperature settings on the basis of the assimilate balance: A simulation study. Acta Hortic. 2006, 718, 219-226. [CrossRef]

14. Lund, J.B.; Andreassen, A.; Ottosen, C.-O.; Aaslyng, J.M. Effect of a dynamic climate on energy consumption and production of Hibiscus rosa-sinensis L. in greenhouses. HortScience 2006, 41, 384-388. [CrossRef]

15. Ottosen, C.-O.; Rosenqvist, E.; Aaslyng, J.M.; Jakobsen, L. Dynamic climate control in combination with average temperature control saves energy in ornamentals. Acta Hortic 2005, 691, 133-140. [CrossRef]

16. Aaslyng, J.M.; Ehler, N.; Karlsen, P.; Rosenqvist, E. IntelliGrow: A component-based climate control system for decreasing greenhouse energy consumption. Acta Hortic. 1999, 507, 35-41. [CrossRef] 
17. Heins, R.D.; Liu, B.; Runkle, E.S. Regulation of crop growth and development based on environmental factors. Acta Hortic. 2000, 511, 15-24. [CrossRef]

18. Fink, M. Effects of short-term temperature fluctuations on plant growth and conclusions for short-term temperature optimization in greenhouses. Acta Hortic. 1993, 328, 147-154. [CrossRef]

19. De Koning, A.N.M. Long-term temperature integration of tomato. Growth and development under alternating temperature regimes. Scientia Hortic. 1990, 45, 117-127. [CrossRef]

20. Liebig, H.-P. Temperature integration by kohlrabi growth. Acta Hortic. 1988, 230, 371-380. [CrossRef]

21. Dieleman, J.A.; Meinen, E.; Dueck, T.A. Effects of temperature integration on growth and development of roses. Acta Hortic. 2005, 691, 51-58. [CrossRef]

22. Körner, O.; Challa, H. Temperature integration and process-based humidity control in chrysanthemum. Comput. Electron. Agric. 2004, 43, 1-21. [CrossRef]

23. Boldt, J.K.; Gesick, E.Y.; Meyer, M.H.; Erwin, J.E. Alternative periodic energy-efficient light and temperature strategies for herbaceous ornamental production. HortScience 2011, 46, S354.

24. Boldt, J.K. Short-term reductions in irradiance and temperature minimally affect growth and development of five floriculture species. HortScience 2018, 53, 33-37. [CrossRef]

25. Blanchard, M.G.; Runkle, E.S. Quantifying the thermal flowering rates of eighteen species of annual bedding plants. Scientia Hortic. 2011, 128, 30-37. [CrossRef]

26. Vaid, T.M.; Runkle, E.S. Developing flowering rate models in response to mean temperature for common annual ornamental crops. Scientia Hortic. 2013, 161, 15-23. [CrossRef]

27. LeBude, A.V.; Bilderback, T.E. The Pour-Through Extraction Procedure: A Nutrient Management Tool for Nursery Crops; AG-717-W; NC State University Coop Extension Publication: Raleigh, NC, USA, 2009.

28. Blanchard, M.G.; Runkle, E.S.; Fisher, P.R. Modeling plant morphology and development of petunia in response to temperature and photosynthetic daily light integral. Scientia Hortic. 2011, 129, 313-320. [CrossRef]

29. Niu, G.; Heins, R.D.; Cameron, A.C.; Carlson, W.H. Day and night temperatures, daily light integral, and $\mathrm{CO} 2$ enrichment affect growth and flower development of pansy (Viola $\times$ wittrockiana). J. Am. Soc. Hortic. Sci. 2000, 125, 436-441. [CrossRef]

30. Munir, M.; Jamil, M.; Baloch, J.; Khattak, K.R. Growth and flowering of Antirrhinum majus L. under varying temperatures. Int. J. Agric. Biol. 2004, 6, 173-178.

31. Pramuk, L.A.; Runkle, E.S. Modeling growth and development of celosia and impatiens in response to temperature and photosynthetic daily light integral. J. Ame. Soc. Hortic. Sci. 2005, 130, 813-818. [CrossRef]

32. Warner, R.M.; Erwin, J.E. Prolonged high temperature exposure and daily light integral impact growth and flowering of five herbaceous ornamental species. J. Am. Soc. Hortic. Sci. 2005, 130, 319-325. [CrossRef]

33. Mattson, N.S.; Erwin, J.E. Temperature affects flower initiation and development rate of Impatiens, Petunia, and Viola. Acta Hortic. 2003, 624, 191-197. [CrossRef]

34. Kaczperski, M.P.; Carlson, W.H.; Karlsson, M.G. Growth and development of Petunia $\times$ hybrida as a function of temperature and irradiance. J. Am. Soc. Hortic. Sci. 1991, 116, 232-237. [CrossRef]

35. Mattson, N.S.; Erwin, J.E. The impact of photoperiod and irradiance on flowering of several herbaceous ornamentals. Sci. Hortic. 2005, 104, 275-292. [CrossRef]

36. Winter, K.; Königer, M. Dry matter production and photosynthetic capacity in Gossypium hirsutum L. under conditions of slightly suboptimum leaf temperatures and high levels of irradiance. Oecologia 1991, 87, 190-197. [CrossRef] [PubMed]

37. Javanmardi, J.; Rahemi, M.; Nasirzadeh, M. Physiological and reproductive responses of tomato and pepper transplants to low-temperature conditioning. Int. J. Veg. Sci. 2013, 19, 294-310. [CrossRef]

38. Ruiz-Espinoza, F.H.; Murillo-Amador, B.; García-Hernández, J.L.; Fenech-Larios, L.; Rueda-Puente, E.O.; Troyo-Diéguez, E.; Kaya, C.; Beltrán-Morales, A. Field evaluation of the relationship between chlorophyll content in basil leaves and a portable chlorophyll meter (SPAD-502) readings. J. Plant Nutr. 2010, 33, 423-438. [CrossRef]

39. Currey, C.J.; Erwin, J.E. Photosynthetic daily light integral impacts growth and flowering of several kalanchoe species. HortTechnology 2011, 21, 98-102. [CrossRef] 
40. Faust, J.E.; Holcombe, V.; Rajapakse, N.C.; Layne, D.R. The effect of daily light integral on bedding plant growth and flowering. HortScience 2005, 40, 645-649.

41. Adams, S.R.; Pearson, S.; Hadley, P. An analysis of the effects of temperature and light integral on the vegetative growth of pansy cv. Universal Violet (Viola $\times$ wittrockiana Gams.). Ann. Bot. 1997, 79, $219-225$. [CrossRef] 